\title{
Analisis Kasih Karunia Dalam Kerelaan Memberi Jemaat Makedonia Berdasarkan 2 Kor 8:1-5 dan Implementasinya Dalam Pelayanan GPIA Newlife Batam
}

\author{
Yenny, ${ }^{1 *}$ Susilo Susanto ${ }^{2}$, Ronald Sianipar ${ }^{3}$, Sabar Manahan Hutagalung ${ }^{4}$ David \\ Martinus Gulo \\ 1,2,3, 4,5 Prodi Teologi, STT Real Batam \\ yen.gho77@gmail.com
}

\begin{abstract}
By God's Grace, the Macedonian Churches responded to the Apostle Paul's invitation. By earnestly giving themselves to God and also to the Apostle Paul. In very poor circumstances but their hearts overflowed with thanksgiving they even urged the Apostle Paul to accept their gift. This is concrete evidence of God's grace experienced by the Macedonian people. The earnest hearts of the Macedonian churches were moved by the grace of God that they experienced. What the Macedonian church did is an example and a necessary example for the churches of today in terms of giving offerings. Offerings driven by God's Grace bring joy and peace both in times of trouble or shortage or in abundance. This study uses a qualitative method of literature study.
\end{abstract}

Keywords: Grace, Willingness, Giving,

\begin{abstract}
Abstrak
Oleh Kasih Karunia Tuhan, Jemaat-jemaat Makedonia merespon ajakan Rasul Paulus. Dengan sungguh-sungguh memberi diri mereka kepada Allah dan juga kepada Rasul Paulus. Dalam keadaan yang sangat miskin tetapi hati mereka meluap dengan ucapan syukur bahkan mereka mendesak Rasul Paulus untuk menerima pemberian mereka. Ini adalah bukti konkret dari kasih karunia Tuhan yang dialami oleh orang-orang Makedonia. Kesungguhan hati jemaat-jemaat Makedonia digerakkan oleh kasih karunia Allah yang mereka alami. Apa yang dilakukan oleh jemaat Makedonia merupakan contoh dan teladan yang perlu bagi jemaat-jemaat masa kini dalam hal memberi persembahan. Persembahan yang digerakkan oleh Kasih Karunia Tuhan mendatangkan suka cita dan damai sejahtera baik dalam masa-masa sulit atau kekurangan maupun dalam kelimpahan. Penelitian ini menggunakan metode kualitatif studi literatur kepustakaan.

Kata kunci: Kasih Karunia, Kerelaan, Memb
\end{abstract}




\section{PENDAHULUAN}

Kekristenan sangat identik dengan kasih yang tulus dan mengajarkan untuk hidup saling berbagi bukan hidup bagi diri sendiri. Tuhan Yesus adalah teladan utama dalam soal memberi. Allah begitu mengasihi ciptaannya manusia sehingga Bapa mengaruniakan anak-Nya yang tunggal Yesus Kristus agar semua orang yang mempercayai-Nya memiliki hidup yang kekal (Yohanes $3: 16$ ).

Pada bagian yang lain juga Alkitab menjelaskan bahwa lebih berbahagia orang yang memberi dari pada menerima (Kis 20:35). Pemberian itu bukan hanya berupa uang tetapi juga memberi diri, tenaga, pikiran, perhatian dan lain sebagainya untuk memuliakan nama Tuhan. Tidak bisa dipungkiri dana atau uang pastilah sangat di butuhkan dalam gereja. Uang menjadi hal yang penting baik untuk biaya operasional ibadah setiap hari minggu maupun untuk program kegiatan lainnya seperti penginjilan, ataupun membeli peralatan seperti alat musik dan lainnya. Sebab itu dalam Alkitab baik Perjanjian Lama maupun Perjanjian Baru, Tuhan selalu mengajarkan kepada umatnya untuk memberi persembahan. Dari mulai persembahan Kain dan Habel, dimana Alkitab mencatat dalam kitab Kejadian 4:4 Habel yang adalah seorang peternak yang tulus memberikan korban persembahannya berupa anak sulung dari kambing dombanya yang terbaik dari hasil ternaknya, semuanya ia persembahkan kepada Tuhan dan apa yang dilakukannya membuat Tuhan mengindahkan Habel dan persembahannya.

Alkitab mencatat bahwa selalu ada korban syukur yang selalu di berikan kepada Tuhan berupa persembahan, baik berupa uang atau emas ,perak, tembaga dan berupa ternak sebagai kurban bakaran, bahkan bagi orang yang di anggap miskin sekalipun mereka tetap membawa persembahan kepada Tuhan.

Demikian juga mengenai prinsip di dalam Perjanjian Baru memberi persembahan adalah ekspresi kasih, sebagai respons akan anugerah Kasih Karunia Tuhan yang telah berikan kepada kita. Jika orang percaya mengerti dan memahami arti pengorbanan Yesus diatas kayu salib untuk keselamatan jiwanya maka hal memberi persembahan adalah hal yang menyenangkan dan mereka akan berbahagia dan bersukacita setiap kali mereka boleh memberi bagi pekerjaan Tuhan. Mereka akan lebih bertanggung jawab akan kekayaan yang di percayakan pada mereka. Bentuk ekspresi dan respon yang benar akan anugerah Kasih Karunia Tuhan atas seseorang dapat terlihat ketika ia menggunakan harta atau uang yang ada padanya. 


\section{METODE}

Metode Jenis penelitian yang digunakan pada tulisan ini menggunakan jenis penelitian kualitatif studi literatur kepustakaan. Diantara alasan penggunaan dari studi literatur kepustakaan ini adalah karena penelitian ini mencoba menganalisis Kasih Karunia dalam kerelaan memberi jemaat Makedonia berdasarkan 2Korintus 8:1-5 dan implementasinya dalam pelayanan GPIA New Life.

\section{HASIL DAN PEMBAHASAN}

\section{Jemaat Makedonia}

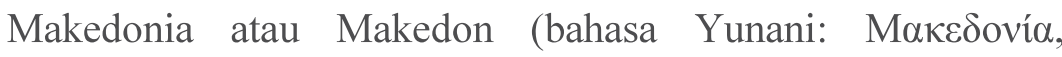
Makedonía) adalah sebuah kerajaan kuno yang terletak di pinggiran Yunani pada masa Arkais dan Klasik, dan kemudian menjadi negara yang dominan di Yunani pada masa Helenistik. Pada awalnya, Makedonia berbatasan dengan Epiros di barat, Paionia di utara, Thrakia di timur, dan Thessalia di selatan.

Kalau kita membaca 2 Korintus 8:1-2 menjelaskan dengan gamblang tentang keadaan jemaat-jemaat Makedonia. Pertama, hal yang menarik dari pernyataannya, Rasul Paulus mengatakan bahwa jemaat-jemaat Makedonia dianugerahkan Kasih Karunia. Kedua, bahwa anugerah Kasih Karunia yang dialami oleh jemaat-jemaat Makedonia telah berbuahkan kemurahan hati yang luar biasa untuk ikut ambil bagian dalam upaya memberikan bantuan bagi jemaat Yerusalem yang juga dilanda resesi krisis ekonomi yang hebat. Jemaat-jemaat Makedonia bukanlah jemaat yang memiliki harta kekayaan yang banyak, tetapi melalui suratnya ia menjelaskan keadaan mereka sangat miskin dan juga ada banyak pelbagai penderitaan yang mereka alami. Kata miskin yang di pakai Rasul Paulus untuk menggambarkan keadaan jemaat Makedonia adalah Kata Yunani ptókos. ${ }^{1}$

Pada bagian berikut dari 2Korintus 8:3-5 Rasul Paulus bersaksi bahwa jemaat Makedonia memberi, bukan saja menurut kemampuan mereka tetapi bahkan melampaui kemampuan mereka. Ini menandakan bahwa mereka "Tidak Kuatir" akan keadaan mereka, sebab mereka menyadari akan kasih Karunia Tuhan Yesus yang telah

1 “MTPJ 17 - 23 Januari 2016," Sinode GMIM, last modified 2016, https:/www.gmim.or.id/mtpj-17-23-januari-2016/. 
memberikan keselamatan yang tidak dapat di nilai uang atau dengan segala bentuk materi apapun. Jemaat-jemaat Makedonia memberi dengan kerelaan hati (2Kor 8:4) artinya bahwa bukan karena terpaksa atau suatu paksaan mereka mengambil bagian dalam pelayanan ini. Mereka memberi diri mereka secara penuh kepada Allah (2 Kor 8:5).

\section{Deskripsi Analisa Kesadaran Dalam Kerelaan Memberi Jemaat Gpia New Life Batam}

Jemaat GPIA New Life yang beralamat di Ruko Central Sukajadi Blok B1 No. 12 B Batam terdiri dari berbagai lapisan golongan masyarakat ekonomi menengah ke bawah. Menurut data jemaat aktif dewasa berkisar 80 dewasa. Di GPIA New Life ada tiga jenis persembahan yang di lakukan jemaatnya. Pertama, Persembahan Per sepuluhan, Kedua, Persembahan Misi dan yang Ketiga, Persembahan Mingguan dan persembahan untuk acara-acara tertentu seperti untuk acara KKR, Retreat atau Cetak Buku.

Cara memberi persembahan di gereja GPIA New Life tidak seperti kebanyakan gereja-gereja pada umumnya dengan menjalankan kantong kolekte, gereja GPIA New Life menyediakan amplop dan kotak persembahan yang di letakan pada bagian belakang ruang ibadah. GPIA New Life tidak memiliki sesi kusus untuk mengumpulkan persembahan saat di awal, di tengah atau di akhir jam ibadah. Persembahan dapat dibawa kapan saja, ada jemaat yang memasukkan persembahannya pada awal kedatangannya atau pada akhir ibadah dan ada juga yang membawa persembahannya bukan pada hari ibadah. Pada bagian belakang amplop ada pilihan bahwa persembahan yang diberikan itu di tujukan sebagai persembahan Per sepuluhan atau Persembahan Misi atau Persembahan mingguan atau untuk lain-lain misalnya untuk program kegiatan khusus lainnya.

Kesadaran dalam Kerelaan memberi jemaat GPIA New Life dapat dilihat dari banyaknya lembar uang persembahan yang diberikan. Misalkan jumlah persembahan tiga ratus ribu rupiah. Jemaat yang hadir dua puluh orang. Lembar uang yang ada misalkan empat lembar, masing-masing seratus ribuan dua lembar dan lima puluh ribuan dua lembar. Maka dapat di prediksi bahwa kemungkinan orang yang hadir dari dua puluh orang tersebut maksimum hanya empat 
orang yang memberi persembahan, jika masing-masing orang memberi satu lembar dari persembahan.

Dari observasi langsung yang penulis lakukan, penulis berpendapat bahwa belum semua jemaat GPIA memiliki kesadaran dalam hal memberi, sebab dari setiap minggu masih terlihat bahwa jumlah lembaran uang persembahan yang di kumpulkan tidak sebanding dengan jumlah kehadiran jemaat yang lebih banyak. Artinya bahwa kesadaran rela memberi dari jemaat belum maksimal. Demikian juga dalam hal persembahan persepuluhan belum semua jemaat menyadari dan melakukannya.

\section{Memberi}

Memberi adalah merupakan bagian dari ibadah orang Kristen. Sejak manusia ada dan lahirnya gereja hingga kini, memberi persembahan sering dilakukan dalam setiap ibadah. Dalam kitab Perjanjian Lama dan juga Perjanjian baru, Ibadah memiliki konsep yang sama. Kata ibadah dalam bahasa Ibrani adalah "äbodah", dalam bahasa Arab ibadah. Secara harfiah memiliki arti bakti, hormat, penghormatan. ${ }^{2}$ Kata ibadah dapat juga diartikan sebagai suatu sikap hidup yang menghargai dan menghormati orang lain atau sesuatu yang lebih berkuasa dari dirinya sendiri seperti sesuatu yang Ilahi, di dalamnya ada kesalehan (yang diatur dalam suatu tatacara), yang akibatnya nampak dalam tingkah laku dan aktivitas kehidupan seharihari. ${ }^{3}$

Paul Enns memberi pengertian bahwa konsep dasar dari ibadah adalah pelayanan atau pengabdian seutuhnya dari hidup orang percaya kepada Allah, yang diwujudkan dalam bentuk penyembahan (worship), maupun dalam tingkah laku (work/witness) orang percaya terhadap dunia di sekitar orang percaya ${ }^{4}$

Dalam kitab Perjanjian Lama maupun Perjanjian Baru, kita dapat melihat berbagai peran manusia memberikan persembahan.

\footnotetext{
${ }^{2}$ Gerhard Johannes Botterweck and Helmer Ringgren, Theological Dictionary of the Old Testament Vol.1 (Michigan: Wm. B. Eerdmans Publishing Company, 1997). 24

${ }^{3} \mathrm{G}$ A Buttrick, The Interpreter's Dictionary of the Bible (Nashville: Abingdon Press, 1982). 879

${ }^{4}$ Paul Enns, The Moody Handbook Of Theology: Buku Pegangan Teologi (Malang: Literatur SAAT, 2006).54
} 
Webber dalam Worship Old and New, menunjukkan bahwa sejak Adam, Kain dan Habel, Abraham, Nuh, bangsa Israel di Sinai, lalu di Kanaan dan terus berlanjut hingga Perjanjian Baru, korban persembahan berperan penting dalam menunjukkan bakti dan pelayanan kepada Tuhan, ada berbagai macam pemberian yang di berikan, ada dalam bentuk korban binatang, tuaian, barang hingga uang. ${ }^{5}$

Rasul Paulus dalam 2 Korintus 9:7 menulis bahwa orang percaya dalam hal memberi harus dengan sukacita dan sukarela. Dalam kitab 1Timotius 6:6 Rasul Paulus menghimbau kepada Timotius dengan berkata bahwa ibadah itu kalau disertai rasa cukup akan memberi keuntungan besar.

\section{Memberi Karena Kasih Karunia (2 Kor 8:1-2)}

Rasul Paulus memberitahukan kepada jemaat Korintus tentang dasar yang mendorong jemaat-jemaat Makedonia dalam memberi. Dalam ayat pertama, rasul Paulus memberitahukan kepada jemaat Korintus tentang kasih karunia yang dianugerahkan (diberikan) oleh Allah kepada jemaat-jemaat Makedonia. Jemaat-jemaat makedonia yang dimaksudkan oleh Rasul Paulus adalah jemaat Filipi, jemaat Tesalonika dan jemaat Berea. ${ }^{6}$

Rasul Paulus menulis kepada jemaat Korintus mengenai alasan jemaat-jemaat Makedonia dalam memberi persembahan. Dimulai dengan kalimat "Saudara-saudara, kami hendak memberitahukan kepada kamu tentang kasih karunia yang dianugerahkan kepada jemaat-jemaat di Makedonia" (2 Kor 8:1 TB). Dalam alkitab terjemahan Indonesia sederhana dikatakan "Dan sekarang, Saudara-saudari, kami ingin kalian tahu bagaimana kebaikan hati Allah sudah bekerja di dalam hati saudara-saudari kita jemaatjemaat di propinsi Makedonia".

Dalam Alkitab Terjemahan Baru, kata "Kasih Karunia", di artikan sebagai "Kebaikan Hati Allah" dalam terjemahan Sederhana Indonesia. Artinya bahwa yang menggerakan atau motivasi jemaat

\footnotetext{
${ }^{5}$ Robert E Webber, Worship Old \& New (Grand Rapids: Zondervan Publishing House, 1982).24

${ }^{6}$ J Wesley Brill, Tafsiran Surat Korintus (Bandung: Kalam Hidup, 1993).118
} 
Makedonia untuk memberi persembahan adalah karena "kebaikan hati Allah" atau "Kasih Karunia Allah" yang sudah bekerja dalam hati mereka. Rasul Paulus dalam suratnya kepada jemaat di Efesus menyatakan bahwa keselamatan yang di peroleh orang Kristen hanyalah merupakan kebaikan hati Allah atau pemberian Allah yang diberikan secara cuma-cuma. Jadi seseorang selamat bukan karena melakukan perbuatan baik. Memang Allah yang sudah mengatur hal itu supaya tidak ada seorang pun yang membanggakan dirinya ( Efesus 2:8-9).

Dasar pemberian yang digerakan oleh Kasih Karunia Tuhan atau kebaikan hati Allah yang telah memberikan keselamatan dengan cuma-cuma kepada seseorang akan berbeda dengan pemberian yang di gerakan oleh karena rasa takut tidak diberkati oleh Tuhan, memberi supaya usaha atau pekerjaannya di jaga oleh Tuhan, memberi agar terhindar dari kutuk, atau memberi karena ingin mendapatkan pengakuan dan pujian dari manusia.

Jemaat-jemaat Makedonia memberi persembahan berdasarkan kebenaran yang hakiki yaitu mereka menyadari bahwa Tuhan sudah sangat baik kepada mereka, Tuhan yang telah memberikan keselamatan secara cuma-cuma tanpa harus membayar apa-apa membuat mereka sadar untuk ambil bagian memberi persembahan untuk membantu orang lain yaitu saudara seiman yakni orang-orang kudus yang ada di Yerusalem.

Di ayat yang ke dua pada 2 Kor 8:2 berkata : "Selagi dicobai dengan berat dalam pelbagai penderitaan, suka cita mereka meluap dan meskipun mereka sangat miskin, namun mereka kaya dalam kemurahan"

Biasanya penderitaan membawa kesedihan dan duka, dapat dimaklumi manakala orang-orang dalam kesusahan dan kekurangan tidak dapat membantu orang lain. Namun bagi jemaat-jemaat Makedonia berbeda, seharusnya merekalah orang-orang yang seharusnya diberi bantuan. Tetapi tidak demikian dengan jemaat Makedonia seperti apa yang disaksikan Rasul Paulus karena ia tahu persis keadaan jemaat makedonia. 


\section{Pengertian Kasih Karunia}

Kasih karunia dalam bahasa Ibrani: תן -KHEN, yang berarti, perkenanan, penerimaan. ${ }^{7}$ Sedangkan dalam bahasa Yunani, kasih karunia berasal dari kata $\chi \alpha \rho ı$ - kharis yang diartikan sama yaitu kasih karunia, cinta kasih, kebaikan, hadiah. ${ }^{8}$ Perkenanan yang didasari oleh cinta kasih dan kebaikan yang di berikan Tuhan berupa hadiah secara cuma-cuma itulah kasih karunia.

Allah Bapa memberikan anak-Nya Yesus Kristus kepada manusia sebagai hadiah untuk menyelamatkannya dan menebus manusia yang telah berdosa (Roma 3:23). Karya penebusan itu sesungguhnya tidak layak di terima oleh manusia sebagai hadiah karena keberdosaan yang dilakukannya. Namun oleh karena Kasih Karunia-Nya manusia menerima pengampunan dosa melalui darah anak-Nya Yesus Kristus yang menjadi kurban yang sempurna.

\section{Sumber Kasih Karunia}

Kasih Karunia Tuhan bersumber bukan dari hikmat manusia atau kehebatan dan kepintarannya, atau kekayaan dan kehormatan manusia melainkan sumber kasih karunia ialah Allah atau Yesus sendiri (Yohanes 1:14,17). Alkitab mencatat bahwa Allah atau Yesus lah yang menjadi sumber segala Kasih Karunia, di luar Yesus tidak ada Kasih Karunia, sebab Alkitab berkata Kasih Karunia datang oleh Yesus Kristus bukan yang lain (1Petrus 5:10). Kasih Allah yang terbesar ketika Yesus merelakan diri-Nya di gantung di atas kayu salib dan membiarkan diri-Nya dipukuli dan dicambuk, Ia dihina, di ludah, di tampar, layaknya seorang penjahat, dinyatakan bersalah walaupun Yesus tidak bersalah, bahkan ia menyerahkan hidup-Nya di atas kayu salib untuk menyatakan cinta kasih-Nya bagi semua orang, itulah Kasih Karunia-Nya bagi orang yang mau menerima dan mempercayai-Nya sebagai Tuhan dan juru selamat, itulah Kasih Karunia. Yesus mengaruniakan kepada orang percaya segala berkat rohani di dalam surga (Efesus 1:3).

\footnotetext{
7 "Kasih Karunia," Alkitab Sabda, last modified 2005, https://alkitab.sabda.org/dictionary.php?word=KASIH KARUNIA.

${ }^{8}$ Ibid.
} 


\section{Dampak Kasih Karunia}

Kasih Karunia Tuhan membuat seseorang mampu untuk dapat hidup benar dan hidup dalam kodrat Ilahi. Adapun Karakteristik Kasih Karunia Allah bagi Jemaat Makedonia adalah sebagai berikut:

\section{Murah Hati}

Memahami kasih karunia Allah dengan benar akan membuat seseorang menjadi murah hati. Orang yang menyadari betapa besar Kasih Karunia Tuhan yang datang dalam kehidupannya akan mengalami pertumbuhan rohani yang sehat. Hidupnya tidak di belenggu oleh rasa kuatir akan hari esok (Matius 6:33), tidak kuatir akan kehidupan di masa depan (Ams 23:18), sebab masa depan sungguh ada di dalam Tuhan.

\section{Sukacita Yang Meluap}

Orang-orang yang mengalami kasih Karunia Allah hidupnya selalu bersukacita. Keadaan sesulit apapun tidak dapat menghalangi suka cita orang percaya. Sebab suka cita itu karena buah dari Roh Kudus (Galatia 5: 22-23). Rasul Paulus mengatakan orang-orang yang menerima Firman dengan suka cita dikerjakan oleh Roh Kudus (1Tes1:6). Suka cita mereka meluap sekalipun masalah dan tekanan datang menghampiri mereka, tidak ada apapun yang dapat memisahkan mereka dari kasih Kristus (Rm 8:39). Kasih Karunia yang mereka alami dan rasakan telah membuat jemaat-jemaat Makedonia bersukacita. Mereka memberi persembahan untuk membantu orang lain dengan tulus ikhlas. Hidup mereka membawa keharuman bagi nama Tuhan Yesus Kristus (2Kor 2:15) di tengah-tengah jemaat Korintus.

\section{Semangat Melayani}

Kasih Karunia Tuhan yang menggerakan seseorang untuk lebih giat melakukan pelayanan dalam melanjutkan visi Tuhan di dunia ini. Itulah yang di alami oleh jemaat Makedonia. Sebagai bentuk manifestasi dari kasih Karunia yang mereka alami memampukan mereka untuk memiliki semangat melayani yang tinggi, dengan menuruti apa yang di ajarkan oleh Rasul Paulus kepada mereka. 


\section{Kesetiaan dan Ketaatan}

Karakteristik dari Kasih Karunia yang di alami oleh jemaat Makedonia adalah kesetiaan dan ketaatan. Kesetiaan dan ketaatan mereka tidak dapat di pungkiri, terbukti mereka melakukan apa yang menjadi komitmen mereka, baik di hadapan Allah dan juga di hadapan Rasul Paulus dengan menepati janji mereka untuk memberi bantuan bagi orang-orang kudus di Yerusalem. Dalam kesetiaan dan ketaatan pada komitmen, Jemaat Makedonia tidak memusingkan diri mereka sendiri walaupun keadaan sangat miskin. Kesetian dan Ketaatan Jemaat Makedonia merupakan contoh dan teladan bagi orang yang percaya kepada Kristus.

\section{Kaya Dalam Kemurahan}

Salomo menulis dalam kitab pengkhotbah bahwa segala kekayaan dan harta duniawi merupakan pemberian Allah dan dapat dinikmati dengan suka cita, itu pun karena Karunia Tuhan (Pengkhotbah 5:18), artinya jika seseorang boleh menikmati kekayaannya itu pun karena kasih karunia Allah. Kasih Karunia Allah yang dialami dan dirasakan oleh jemaat Makedonia telah membuat mereka kaya dalam kemurahan. Kaya dalam kemurahan bukan selalu identik dengan berapa banyak harta yang dimiliki oleh seseorang, melainkan seberapa banyak seseorang telah menjadi saluran berkat bagi orang lain.

Jemaat Makedonia sangat miskin, namun kemiskinan mereka tidak dapat menghalangi mereka untuk memberi lebih banyak dari yang diharapkan Rasul Paulus. ${ }^{9}$ Orang yang mengalami kasih Karunia Allah, hidup mereka pasti berdampak bagi orang lain. Hidup mereka mengalami terobosan yang memampukan mereka untuk hidup bijaksana dan kaya dalam kemurahan. Sekalipun sedang mengalami krisis ekonomi, kesukaran dengan macam-macam pencobaan yang berat dan penderitaan, mereka miskin secara harafia, tetapi reaksi mereka berbeda dengan kebanyakan orang, Alkitab mencatat bahwa sukacita mereka meluap, mereka kaya dalam kemurahan (2Korintus

\footnotetext{
${ }^{9}$ Johan Djuandy, "Signifikansi Teologis Pengumpulan Uang Bagi Jemaat Yerusalem," Jurnal Amanat Agung 5, no. 1 (2009): 63-90.70
} 
8:1-2). Artinya bahwa kemiskinan secara harafia yang mereka alami tidak dapat membelenggu hidup mereka untuk memberi persembahan kepada Tuhan, Pemberian mereka bagi jemaat Yerusalem diluar dari ekspetasi yang rasul Paulus pikirkan bahkan mendesak Paulus untuk menerima persembahan Mereka. Mereka adalah orang-orang yang kaya dalam kemurahan, itulah yang dicatat dalam Alkitab. Seharusnya orang-orang Makedonialah yang patut menerima bantuan sebab ekonomi mereka lagi terpuruk dan hidup mereka dikatakan sangat miskin, bukan itu saja, mereka juga di timpa berbagai pencobaan yang berat dan bermacam-macam penderitaan. Tetapi betapa luar biasanya, mereka hidup sebagai orang bermental kaya, bukan sebagai orang bermental miskin yang mengasihani diri sendiri dan bergantung pada belas kasihan orang lain. Mereka adalah orang kaya sejati yang menyadari betapa besar anugerah kasih karunia Tuhan yang telah mereka alami sehingga sukacita mereka selalu meluap. Inilah yang terjadi pada orang-orang yang mengalami kasih karunia Tuhan, mereka tidak berfokus pada diri mereka sendiri, melainkan mereka berfokus pada pekerjaan dan kehendak Tuhan.

Kekayaan yang ada didalam hati atau kekayaan rohani jauh lebih berarti dibandingkan kekayaan jasmani. Kekayaan dalam iman, dalam perkataan, dalam pengetahuan, dalam kesungguhan untuk membantu, dan dalam kasih inilah kekayaan sejati (2 Korintus 8: 7). Ukuran kaya dan miskinnya seseorang tidak di lihat dari seberapa banyak hartanya atau uangnya, tetapi bagaimana hatinya yang melimpah dengan rasa syukur dan menjadi alat saluran berkat bagi orang lain. Sumber kekayaan sejati ada di dalam Kristus Yesus. ${ }^{10}$ Bila Yesus hadir dalam hidup seseorang maka aliran-aliran air hidup itu akan melimpah dan mengalir keluar untuk dinikmati oleh orang lain (Yoh 7:38). Orang yang menabur sedikit akan menuai sedikit juga dan orang yang menabur banyak akan menuai banyak juga (2 Korintus 9:6).

${ }^{10}$ Magdalena Pranata Santoso, ETIKA : Etika Hidup Bermakna (Yogyakarta: Graha Ilmu, 2013).6 


\section{Tahan Uji Dalam Penderitaan}

Kasih Karunia menjadikan sesorang tahan uji dalam penderitaan. Kekuatan seseorang dalam menghadapi masalah dan penderitaan bukan karena ia hebat, atau berdasarkan metode yang dibuat, bukan terletak dari kehebatan ataupun kekuatan dirinya, tidak terletak pada harta atau uangannya, pada jabatannya atau koneksinya, bukan terletak pada gelarnya dan sebagainya, kekuatan seseorang terletak pada kasih karunia Tuhan yang datang dalam hidupnya. Jemaat Makedonia begitu kuat menghadapi penderitaan, mereka tahan uji dalam pelbagai penderitaan yang sangat berat namun oleh karena Kasih Karunia Tuhan yang mereka alami membuat hati mereka melimpah dengan syukur.

\section{Fokus Pada Kehendak Allah}

Kasih Karunia Tuhan yang mereka alami telah memampukan diri mereka untuk berfokus pada hal-hal yang rohani bukan pada halhal yang lahiriah. Seperti Rasul Paulus yang terus fokus pada pemberitaan Injil Kristus dan mengesampingkan keinginan diri sendiri demikian juga Jemaat Makedonia.

Rasul Paulus dalam pelayanannya berkata aku tidak menghiraukan nyawaku sedikitpun, asal saja aku dapat mencapai garis akhir dan menyelesaikan pelayanan yang ditugaskan oleh Tuhan Yesus kepadaku untuk memberi kesaksian tentang Injil kasih karunia Allah (Kisah 20:24). Karena kasih karunia yang bekerja di dalam hidupnya membuat rasul Paulus fokus pada kehendak Allah untuk berjuang, bekerja keras dalam memberitakan Injil kasih karunia-Nya.

\section{Implementasi 2 Kor 8:1-5 Bagi Gereja Secara Umum}

Jemaat-jemaat Makedonia merupakan jemaat yang secara sadar akan pentingnya arti memberi. Mereka sangat luar biasa, walaupun secara ekonomi mereka dikatakan sangat miskin dibanding gerejagereja di Akhaya dan sekitarnya (Korintus). Kasih Karunia Allah yang mereka alami telah menggerakan hati mereka untuk mau berbagi dengan memberi persembahan bagi orang kristen yang ada di Yerusalem. Perbuatan mereka telah berdampak secara luar biasa bagi gereja-gereja yang lain termasuk gereja-gereja masa kini. Sekalipun 
mereka mengalami kesulitan dan penderitaan yang berat dan dikatakan sangat miskin, tetapi mereka sangat kaya dalam kemurahan hati, kepedulian mereka pada orang-orang kudus (orang percaya) merupakan ibadah yang berkenan kepada Tuhan.

Seharusnya apa yang di lakukan oleh jemaat-jemaat Makedonia dalam hal memberi merupakan contoh dan teladan bagi gereja masa kini. Memang secara kasat mata bahwa pemberian yang diberikan ke gereja di pakai oleh manusia, namun kebenarannya bahwa apa yang kita berikan di dunia ini merupakan bagian dari ibadah kita kepada Tuhan. Firman Tuhan berkata "Tetapi kumpulkanlah bagimu harta di sorga; di sorga ngengat dan karat tidak merusakkannya dan pencuri tidak membongkar serta mencurinya" (Matius 6:20). Alkitab mengajarkan bahwa siapa yang menabur sedikit akan menuai sedikit juga, dan orang yang menabur banyak akan menuai banyak juga (2 Korintus 9:6). Hal memberi bukanlah sesutu suatu yang perlu dipaksakan melainkan suatu kerelaan dan suka cita seperti yang dilakukan oleh jemaat Makedonia. Oleh karena itulah apa yang diperbuat oleh jemaat-jemaat Makedonia, seharusnya menjadi tolak ukur yang benar bagi orang kristen pada umumnya dalam hal memberi persembahan kepada Tuhan.

\section{Implementasi 2 Korintus 8:1-5 Bagi Gpia New Life}

Implementasi bagi GPIA New Life, menjangkau jiwa melalui media New Life memulai pelayanannya dengan melakukan siaran televisi secara Live dengan program Acara: Curhat (curahan hati) Bersama New Life di Batam TV. Pada program ini, setiap pemirsa boleh curhat kepada nara umber untuk menceritakan persoalan, pergumulan mereka dan meminta saran-saran apa yang bisa menolong mereka dari problema hidup yang sedang mereka hadapi. Dari program acara curhat bersama New Life cukup banyak orang yang mengalami kemenangan dan menemukan jalan keluar. Dan bagi mereka yang ingin melakukan konsultasi, dan konseling tidak dipungut biaya se persen pun, semua layanan diberikan secara gratis, sehingga semua lapisan masyarakat boleh konsultasi dan konseling.

Selanjutnya GPIA New Life melakukan pelaynan misi kepulau-pulau. Dalam perkembangan dan pertumbuhan GPIA New 
Life, sebagai implikasi dari 2 Korintus 8:1-5, GPIA juga melakukan pelayanan misi ke pulau-pulau, seperti pulau Burung, pulau Tanjung Balai Karimun, SP III yang ada di wilayah Kepri bahkan diluar Kep.Riau seperti, pualu Jawa, pulau Nias, bahkan sampai juga ke tanah Papua untuk memberitakan Injil Kristus . bukan hanya itu saja GPIA New Life membuat pelatihan Misi, pengkaderan kepemimpinan, hingga pelayanan kasih.

\section{KESIMPULAN}

Kasih Karunia yang di anugerahkan kepada Jemaat-Jemaat Makedonia (Filipi, Tesalonika dan Berea) adalah kerelaan dan kesanggupan memberi persembahan yang tulus ikhlas bahkan melebihi dari kemampuan mereka untuk membantu kekurangan orang kudus. Kasih Karunia Allah yang dianugerahkan pada jemaat-jemaat Makedonia membuat hidup mereka berbuahkan kasih dalam membantu kekurangan orang-orang kudus dengan memberi persembahan.

Kerelaan memberi dari Jemaat-jemaat Makedonia di luar kebiasaan banyak orang. Mereka memberi menurut kemampuan bahkan lebih dari kemampuan, mereka memberi bahkan dari kekurangan mereka. Situasi dan kondisi tidak menghalangi mereka untuk berdiam diri. Kerelaan memberi berdasarkan dorongan kasih karunia Allah yang di anugerahkan kepada mereka suatu kerelaan memberi dengan hati yang tulus ikhlas.

Implementasi Kasih Karunia dalam kerelaan memberi jemaat GPIA New Life Batam secara keseluruhan belum maksimal, ini dapat terlihat dari jumlah kehadiran jemaat yang tidak sebanding dengan banyaknya lembar uang yang ada pada kotak persembahan. Tetapi walaupun demikian, sebagian besar Jemaat telah memberikan persembahan dengan suatu kerelaan dan dengan kesadaran yang baik. Sampai saat ini Kasih Karunia Tuhan Yesus tetap memelihara GPIA New Life sehingga penyelenggaraan penggembalaan terus berjalan dengan baik.

\section{KEPUSTAKAAN}

Botterweck, Gerhard Johannes, and Helmer Ringgren. Theological Dictionary of the Old Testament Vol.1. Michigan: Wm. B. Eerdmans Publishing Company, 1997.

Brill, J Wesley. Tafsiran Surat Korintus. Bandung: Kalam Hidup, 1993.

Buttrick, G A. The Interpreter's Dictionary of the Bible. Nashville: Abingdon Press, 1982. 
Djuandy, Johan. "Signifikansi Teologis Pengumpulan Uang Bagi Jemaat Yerusalem." Jurnal Amanat Agung 5, no. 1 (2009): 63-90.

Enns, Paul. The Moody Handbook Of Theology: Buku Pegangan Teologi. Malang: Literatur SAAT, 2006.

Santoso, Magdalena Pranata. ETIKA : Etika Hidup Bermakna. Yogyakarta: Graha Ilmu, 2013.

Webber, Robert E. Worship Old \& New. Grand Rapids: Zondervan Publishing House, 1982.

"Kasih Karunia." Alkitab Sabda. Last modified 2005. https://alkitab.sabda.org/dictionary.php?word=KASIH KARUNIA.

“MTPJ 17 - 23 Januari 2016." Sinode GMIM. Last modified 2016. https://www.gmim.or.id/mtpj-17-23-januari-2016/. 